Provided for non-commercial research and education use. Not for reproduction, distribution or commercial use.

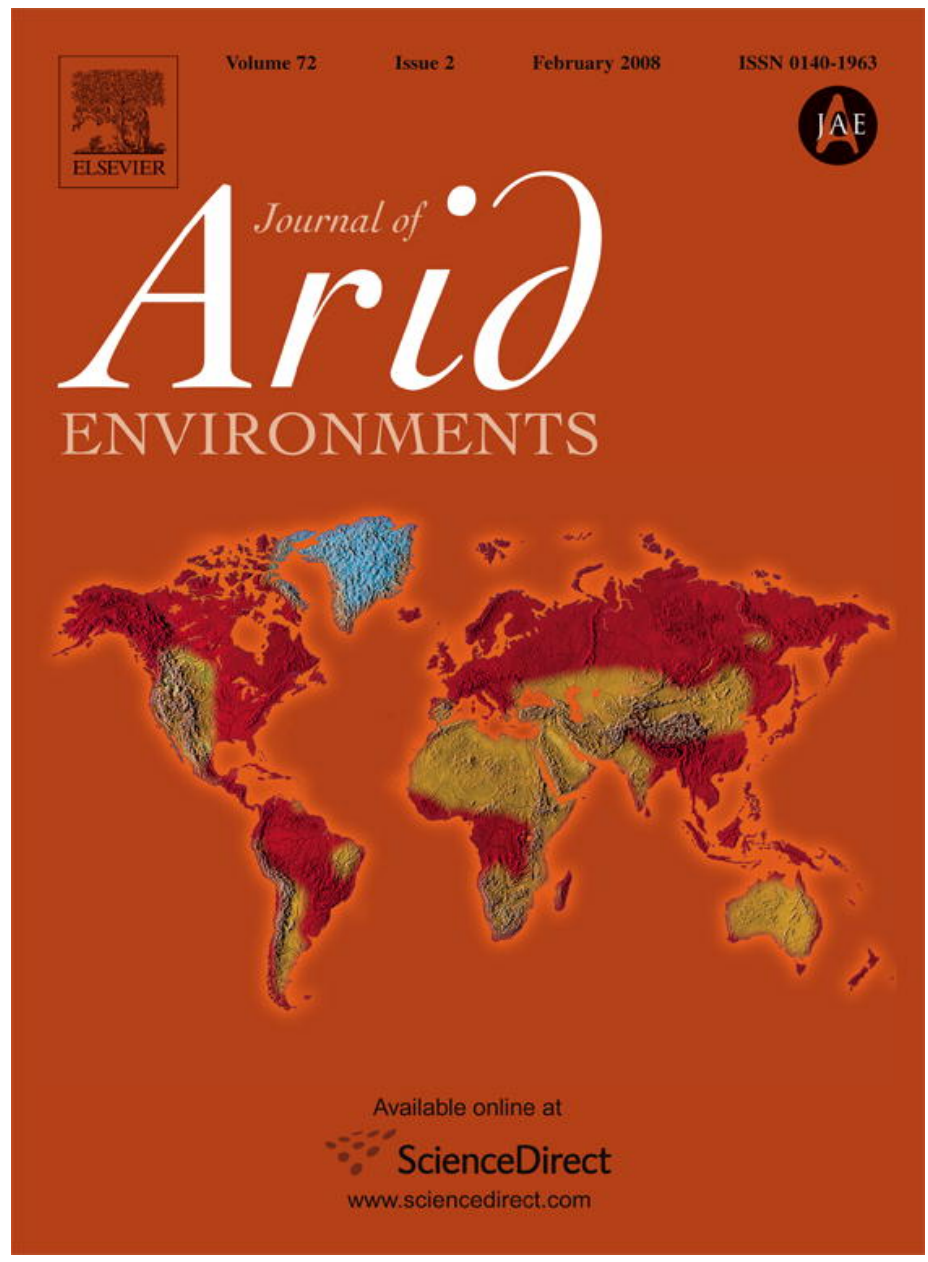

This article was published in an Elsevier journal. The attached copy

is furnished to the author for non-commercial research and education use, including for instruction at the author's institution, sharing with colleagues and providing to institution administration.

Other uses, including reproduction and distribution, or selling or licensing copies, or posting to personal, institutional or third party websites are prohibited.

In most cases authors are permitted to post their version of the article (e.g. in Word or Tex form) to their personal website or institutional repository. Authors requiring further information regarding Elsevier's archiving and manuscript policies are encouraged to visit: 


\title{
Fifty years of landscape evolution in Southwestern Mauritania by means of aerial photos
}

\author{
A.J. Niang ${ }^{\mathrm{a}}$, A. Ozer ${ }^{\mathrm{a}}$, P. Ozer ${ }^{\mathrm{b}, *}$ \\ ${ }^{a}$ Department of Geography, Liege University, Allée du 6 Août 2, B-4000 Liège, Belgium \\ ${ }^{\mathrm{b}}$ Environmental Sciences and Management Department, Liege University, Avenue de Longwy 185, B-6700 Arlon, Belgium
}

Received 9 December 2005; received in revised form 14 September 2006; accepted 21 April 2007

Available online 8 June 2007

\begin{abstract}
South-western Mauritania is located in a semi-arid environment exposed to large rainfall variations and affected by a severe drought since the mid-1960s. The studied area includes the right bank of the Senegal River and the southern extension of the Saharan sandy dunes and is based on the analysis of climatic data, field studies, and four aerial surveys realized since 1954.

The climatic analysis shows that, after a strong decline of yearly rainfall started in the mid-1960s, a significant increase is observed from the early 1990s. In the meantime, dust storms frequency has dramatically increased while the threshold wind speed declined as a result of vegetation contraction. The comparison of the four mosaics of aerial photos reveals the major impact of both drought and human on recent environment changes with the strong decline of the forest, the reactivation of sandy soils and the apparition of large rice fields.

If the increase of active dunes activity is likely to be a consequence of the persisting drought, forest decline is more likely to be attributed to fuel wood collection in a first time, then to the creation of rice fields since the late 1980s. Although the 2003 aerial photos show a timid return of vegetation in very limited and specific areas, field surveys show that wind erosion is still very important and water erosion is developing very rapidly because of the absence of vegetation cover.
\end{abstract}

(C) 2007 Elsevier Ltd. All rights reserved.

Keywords: Desertification; Land cover change; Senegal River Valley; Wind erosion

\section{Introduction}

South-western Mauritania is located in a semi-arid environment exposed to large rainfall variations. During the Quaternary, the study area has experienced a long morphodynamic evolution submitted to very different paleoclimates. Soils are characterized by sandy dunes that developed during the latest arid phase of the ogolian period (between 18,000 and 12,000 BP). These sandy formations are oriented in a North-East to South-West direction.

\footnotetext{
*Corresponding author. Tel.: + 32063230975 ; fax: + 32063230800 .

E-mail addresses: ajeniang@yahoo.fr (A.J. Niang), pozer@ulg.ac.be (P. Ozer).
} 
This sandy dunes scheme is abruptly stopped by the alluvial plain of the Senegal River, which appears like a $10-25 \mathrm{~km}$ wide depression covered by alluvial deposits with a very low relief. The geomorphological evolution is linked to climatic variations and sea level changes because of the very flat slope of the Senegal River.

The rainfall regime of the study area is characterized by great variability in both time and space. Even within short distances, rainfall may be very different (Sivakumar and Hatfield, 1990). Climate is characterized by a short rainy season, largely limited to the months of July-September, as well as the North-South gradient of the mean annual rainfall (Ozer, 2000). Over the last decades, the Sahel of West Africa has been affected by a severe drought (Dai et al., 2004; L'Hôte et al., 2002; Ozer, 2000). These long-time rainfall shortages have not only affected natural vegetation and stream flows but also socio-economical activities. In Mauritania, above $90 \%$ of the population was rural 40 years ago, dominated by agriculture in the southern belt and by pastoralism in the central and northern zones of the country, most inhabitants being nomads. From the mid1960s, the long-term drought killed most of the livestock and forced nomad population to settle creating new villages or enlarging small cities (Arnaud, 1999). Many others moved towards the capital Nouakchott with a population that increased from 6000 in 1962 to 535,000 in 1988 and to above 760,000 in 2001 (Salama et al., 1991; UNFPA, 2005).

The precariousness of hydroclimatic conditions has led to the large hydrological works conducted to optimize water resources management of the Senegal River basin for agricultural purposes. Large dams were constructed in the late 1980s. One is upstream, Manantali, in order to allow irrigated agriculture in all seasons. The other one is located downstream, Diama, to prevent the intrusions of salted sea water.

The area on which we focus here is the Trarza region (Fig. 1) and is delimited between $15^{\circ} 30^{\prime}$ and $14^{\circ} 40^{\prime} \mathrm{W}$, and $17^{\circ} 50$ and $15^{\circ} 30 \mathrm{~N}$. The northern part of the study area is characterized by desert-like conditions. The southern area is part of the traditionally called "sahelian belt" that is exposed to desertification processes.

Recent papers suggested that the Sahel of West Africa has been greening during the last decade (Eklundh and Olsson, 2003; Olsson et al., 2005; Pearce, 2002). Changes in precipitation were identified as the primary driver of the greening trend of the Sahel vegetation and its interannual variability between 1982 and 1998 (Hickler et al., 2005), although Anyamba and Tucker (2005) emphasize that the NDVI time series commenced

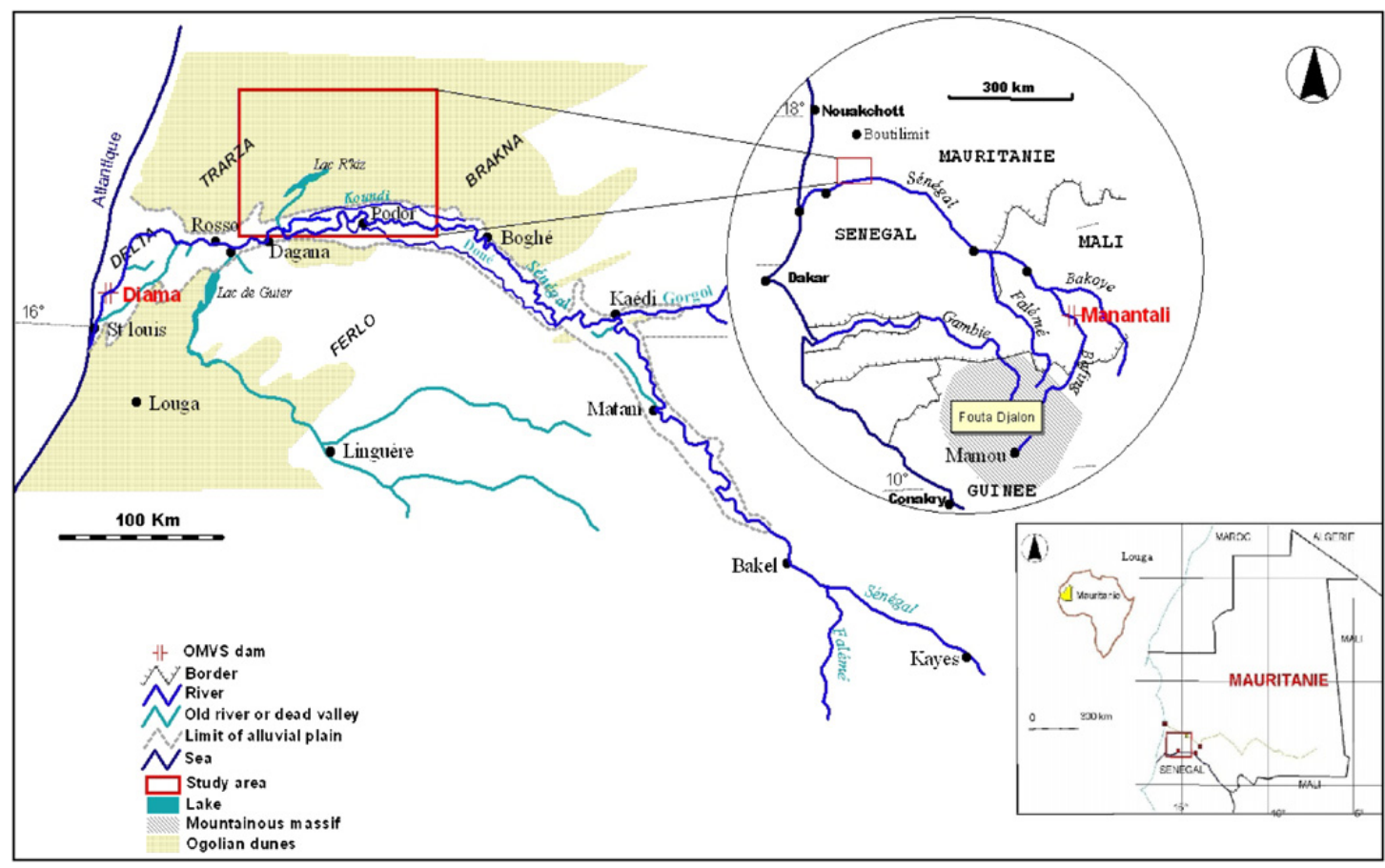

Fig. 1. Geographical position of the study area. 
during a historically intense drought (the early 1980s) and that the recent gradual recovery has likely not returned vegetation to pre-drought conditions of the 1950s and 1960s. However, the resilience of vegetation to rainfall is not evident everywhere and the idea of "greening Sahel" has been challenged by some authors (Hiernaux and Turner, 2002; Hountondji et al., 2006; Ozer and Ozer, 2005). But all these works are realized at a regional scale. Other studies based on original field data showed that forest species richness and tree density in the West African Sahel declined in the last-half of the 20th century (Gonzalez, 2001). Therefore, at the local scale, forest parameters more effectively demonstrate long-term environmental trends.

In this paper, local environmental evolution is analyzed over the last 50 years with climatic data (daily rainfall, wind speed and dust related conditions), field studies, and four aerial surveys realized in 1954, 1972, 1992 and 2003 in order to estimate latest trends in land cover.

\section{Materials and methods}

\subsection{Climate data}

Daily rainfall data from the origin of the station until 2001 for the station of Boutilimit were made available from an archive assembled by the Agrhymet representation in Mauritania.

The meteorological horizontal visibility is one of the elements world-widely identifying air mass characteristics. In synoptic stations, it is observed on a 3-hourly basis and defined as the greatest horizontal distance at which a black object of suitable dimensions, located near the ground can be seen and recognized when observed against a background scattering of hydrometeors (rain, snow, fog, mist) or lithometeors (dust processes) (WMO, 1992). The international synoptic surface observation code (SYNOP code) allowed the identification of local wind erosion conditions (WMO, 1996). In the purpose of this paper, we therefore used the two following classes of observation as a proxy indicator of wind erosion:

(1) dust being raised from the ground at the time of the observation $(07,08)$ and reducing horizontal visibility to less than $5 \mathrm{~km}$ (blowing dust);

(2) dust storms, resulting of turbulent wind systems entraining particles of dust into the air, at various degrees of intensity $(09,30,31,32,33,34,35,36)$ reducing horizontal visibility to below $1 \mathrm{~km}$.

Data on dust related conditions were digitized from the 3-hourly time-scale synoptic observations made in Boutilimit and archived at the meteorological office of Mauritania. They cover the 1951-1998 period. Later records were not used as they are not reliable due to the absence of observers since the late 1990s. Each day was qualified as without dust being raised from the ground or as with deflation (or wind erosion) for days with observed blowing dust and/or dust storm.

Data on wind speed recorded at $6 \mathrm{~m}$ height were also digitized from the 3-hourly time-scale synoptic observations. Here, the highest wind speed of the day was automatically selected. The data at the station of Boutilimit cover the 1951-1998 and later records are not reliable due to the bad conditions of the anemometer (Ozer, 2000).

\subsection{Airborne data}

The study has drawn upon various sources of information, including topographical map, aerial photos and satellite pictures. Aerial photos of 1954 and 1992 were ordered from the French Institut Géographique National (IGN) (http://www.ign.fr). Intelligence imagery acquired by the first generation of United States photo-reconnaissance satellites, including the code-named CORONA, were declassified on 24 February 1995 and ordered to the United States Geological Survey (USGS) (http://earthexplorer.usgs.gov). Other airborne data collected during a recent survey were made available from the Maps Geosystems private company. In addition, field observations and collection of data has been carried out. The most important data sources are briefly listed in Table 1. 
Table 1

Aerial photos and satellite pictures used for this study

\begin{tabular}{llllll}
\hline Date & Mission & Reference & Characteristics & Scale/resolution & Type and origin \\
\hline 20/01/1954 & AOF 1954 & 088 & Black and white & $1: 50,000$ & Aerial photos (IGN France) \\
$24 / 04 / 1972$ & CORONA 1116-1 & DS1116-1075DA043 & Black and white & $1: 37,000$ & Declassified Satellite imagery (USA) \\
$20 / 11 / 1992$ & MAU 1992 & $014 / 400$ & Black and white & $1: 40,000$ & Aerial photos (IGN France) \\
$23 / 04 / 2003$ & OMVS & n/a & RGB & $0.5 \mathrm{~m}$ & Aerial photos (Maps geosystems, Canada) \\
\hline
\end{tabular}

\subsection{Methodology}

\subsubsection{Climate}

Rainfall data are analyzed using annual total precipitation. The nonparametric Pettitt (1979) statistical test was applied in order to identify potential abrupt changes in the series. In addition, in order to retrieve the threshold wind speed at Boutilimit, the daily maximum wind speed and the associated observed deflation events were plotted in the form of frequency diagrams for each station. A $10 \%$ frequency of the deflation events was chosen to estimate the threshold wind speed.

\subsubsection{Aerial photos}

Differences in the time of year of aerial photo coverage, as well as in quality and processing, make quantitative analysis of changes between the four sets of photos difficult. However, certain objects and features may be identified visually on the basis of pattern and shape. These include:

- Dense individual trees over a certain size that may be called "forest".

- Active eolian surface morphology.

- Human habitations.

- Rice fields that clearly appear of aerial photos with well-defined linear boundaries.

Fig. 2 shows an example of these analyzed land covers. All topographical map, aerial photos and satellite pictures have been scanned and comparisons were realized in Erdas imagine et Arcview. After a geometric correction, aerial photos and satellite pictures were mosaiced. Digitalizations made on different data sources have superposed in order to quantify land use cover changes.

\section{Results and discussions}

\subsection{Climatic evolution}

\subsubsection{Rainfall}

The analysis of rainfall shows the very high variability of yearly totals that vary from about $10 \mathrm{~mm}$ in 1987 to above $400 \mathrm{~mm}$ in 1955 (Fig. 3). We applied the nonparametric statistical test of Pettitt (1979) in order to find any abrupt changes in the 1923-2001 series of rainfall. Results show a first abrupt change $(p=0.005)$ in 1969 indicating that an intense precipitation deficit started in 1970. This period of drought ended in 1990 $(p=0.006)$. Yet, the 1923-1969 period recorded average yearly rainfall of $191 \mathrm{~mm}$ while the drought of the 1970 s and 1980s recorded $103 \mathrm{~mm}$, a deficit of $46 \%$. Since 1991 , average rainfall is $181 \mathrm{~mm}$, very near predrought conditions.

These results correspond to the trends observed elsewhere in the Sahel of West Africa, with the start of the drought in the late 1960s (Dai et al., 2004; L'Hôte et al., 2002; Ozer, 2000) and wetter conditions in the early 1990s (Nicholson, 2005; Ozer et al., 2003).

\subsubsection{Dust processes and threshold wind speed}

Dust processes have strongly increased during the 1951-1998 period (not shown). From about 20 events per year before the drought, dust events reached an average of above 100 events per year during the drought and 


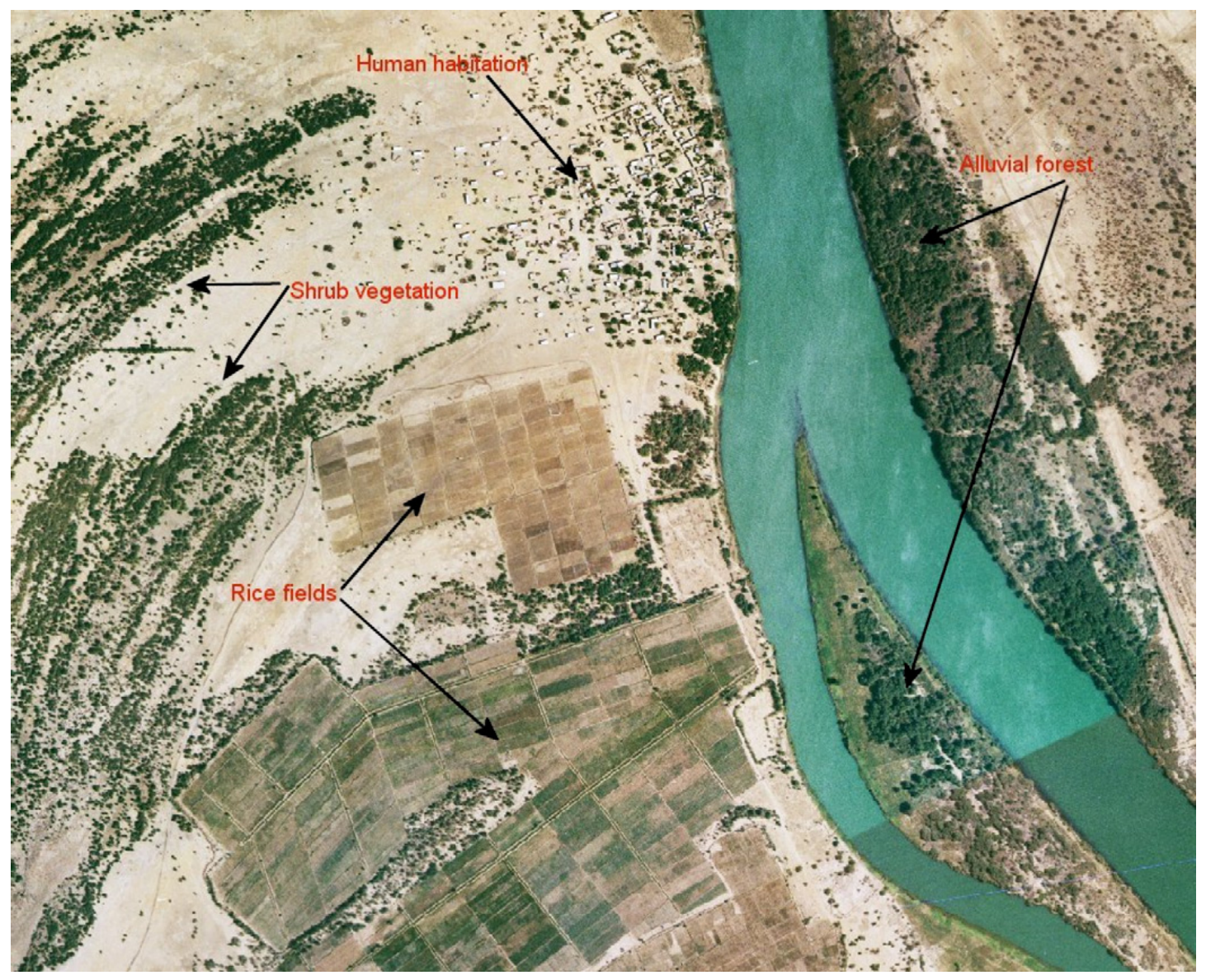

Fig. 2. An example of different land covers characterizing the area of interest.

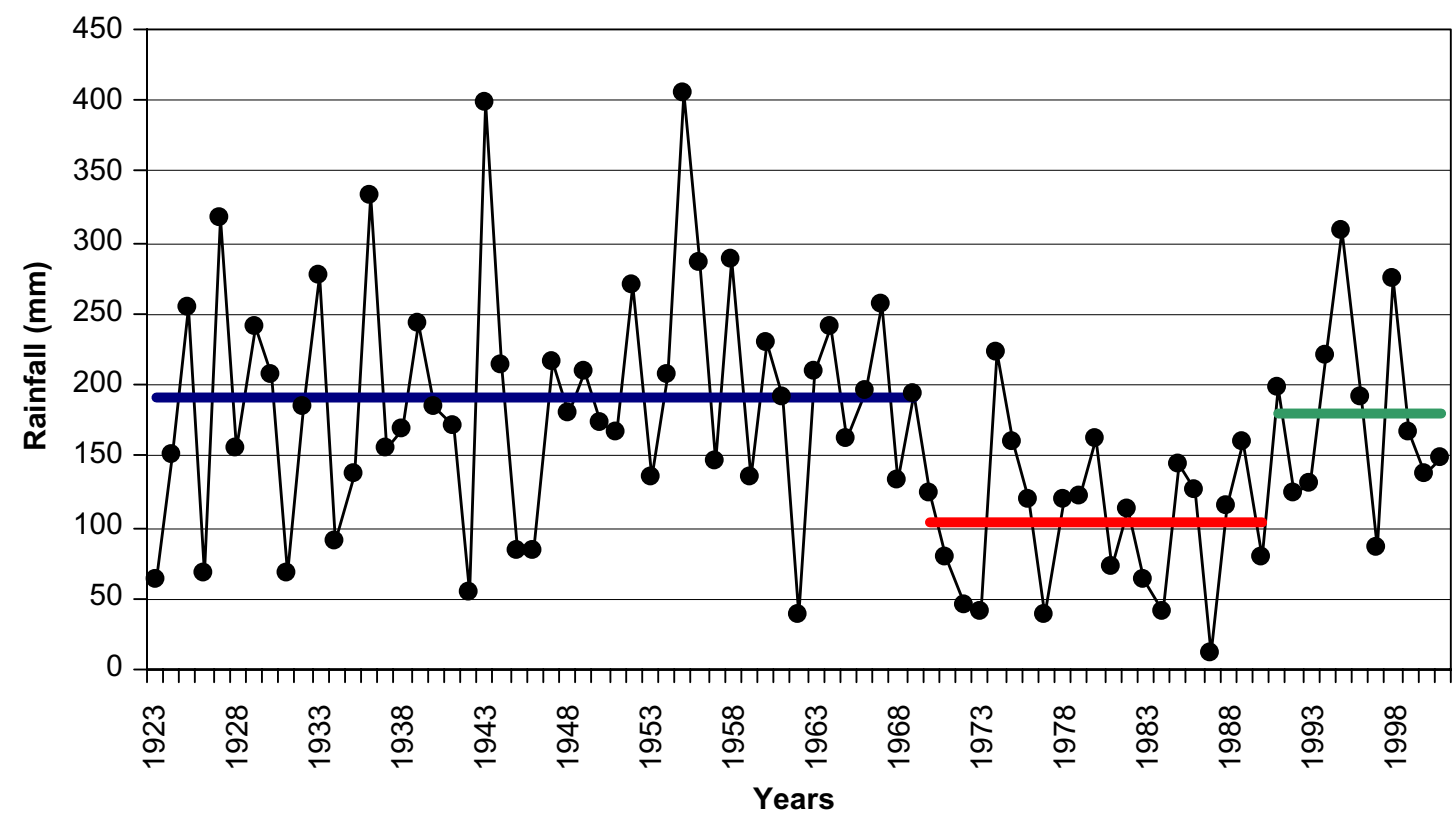

Fig. 3. Rainfall at the station of Boutilimit from 1923 to 2001 . Horizontal lines indicate average rainfall value recorded during the three homogeneous periods of rainfall indicated by the nonparametric statistical test of Pettitt (1979). 
remained stable during the 1990s. This trend is similar to those found anywhere else in Mauritania and in West Africa (Nouaceur, 2003; Ozer, 2000).

The association between dust-raising events and wind speed were calculated for the three climatic periods identified above (1951-1969, 1970-1990 and 1991-1998). The frequency of occurrence of deflation events at Boutilimit is shown in Fig. 4.

The threshold wind speed calculated for dust raising events at the $10 \%$ frequency decreased from $8 \mathrm{~m} \mathrm{~s}^{-1}$ during the 1951-1969 period, to $6 \mathrm{~m} \mathrm{~s}^{-1}$ during the drought and $5 \mathrm{~m} \mathrm{~s}^{-1}$ during the 1990s. The same trend is observed when analyzing wind speed associated with deflation events at the $50 \%$ frequency. From above $12 \mathrm{~m} \mathrm{~s}^{-1}$ during the pre-drought period, it declines to the $8-9 \mathrm{~m} \mathrm{~s}^{-1}$ interval during the drought and to $7 \mathrm{~m} \mathrm{~s}^{-1}$ during the 1990s. The difference between these three periods is systematically very significant $(p<0.005)$. A similar trend was observed in other stations of Mauritania (Ozer, 2000) and can be explained as a result of the degradation of the soil cover enhanced by the drought, overgrazing, wood collection, livestock trampling, and many other reasons that lead to this higher capacity of the wind to provoke erosion. Such assumption will be verified later on when analyzing aerial photos.

\subsection{Landscape changes}

\subsubsection{Land cover change in dunes fields, 1954-1992}

A common area of 3749 ha was selected from the airborne data of 1954, 1972 and 1992 in order to estimate changes in dune features. This area is presented in Fig. 5. Superposition of airborne data shows that the most important changes are observed in the dune morphology. All dunes were fixed by vegetation in 1954. In the early 1970s, very little areas were on the move suggesting that a few years of rainfall shortages are not enough to radically change the landscape. However, 20 years of drought and of human pressure were fatal to previously fixed dunes and wind erosion has become the major morphodynamic process. Vegetation disappeared, from 637 ha in 1954 to 60 ha in 1992, and most dune crests visible from the white spots of the 1992 aerial photo are active (Fig. 5). Despite what has been noted in other places of West Africa, ogolian fossil dunes have been reactivated but none moved southwards.

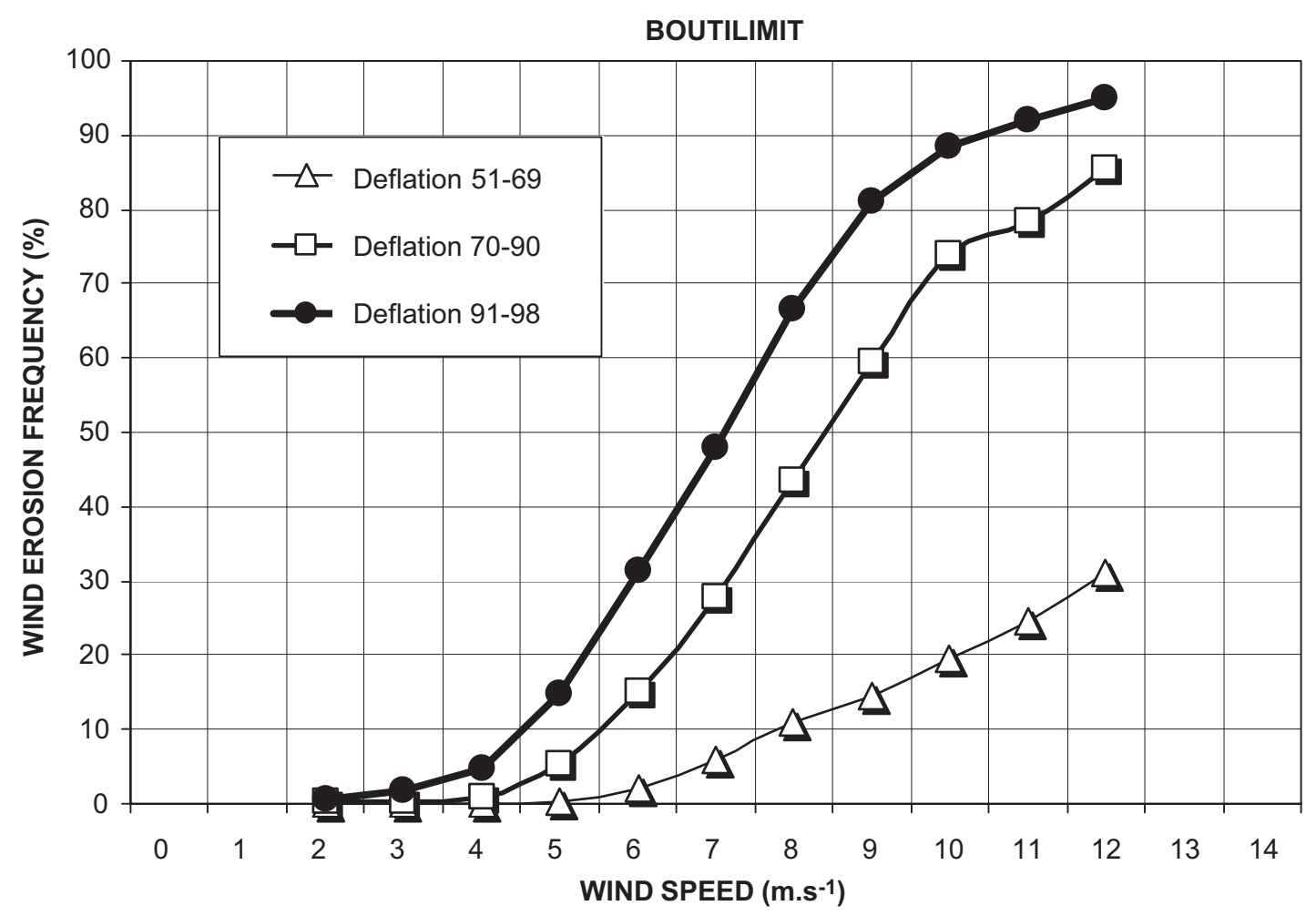

Fig. 4. Frequency of deflation events vs wind speed at Boutilimit during the 1951-1969, 1970-1990, and 1991-1998 periods. 

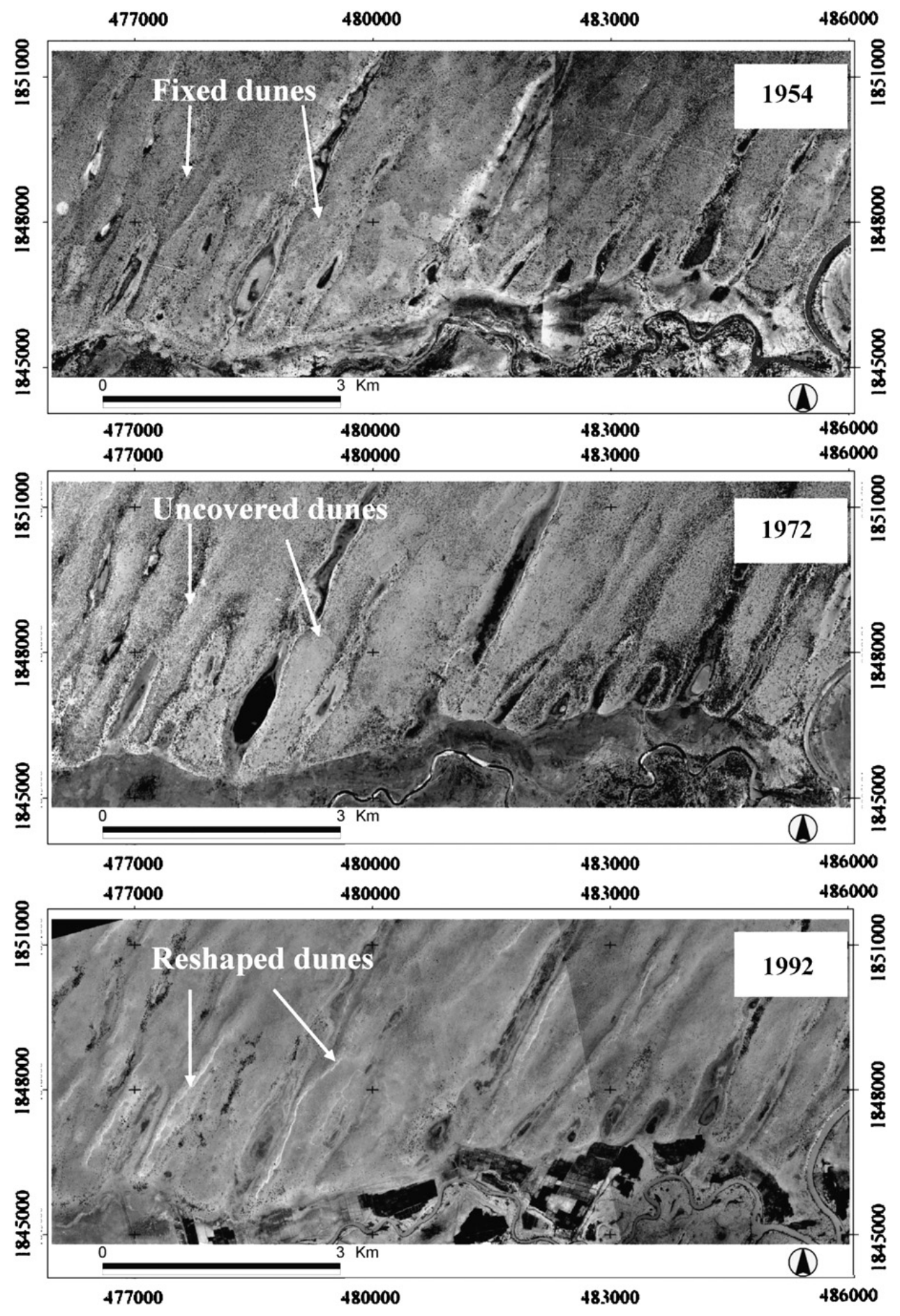

Fig. 5. Changes in the dune features between 1954 and 1992.

Our findings are similar to those observed in other areas of the Sahel, that is a strong degradation of the environment during the early 1980s due to the intensification and the persistence of the rainfall deficit (Ozer, 2000; Rasmussen et al., 2001). In addition, they fit very well with the evolution of the frequency of dust processes noted in Boutilimit and elsewhere in the semi-arid belt of West Africa (Ozer, 2000).

\subsubsection{Land use change in the Senegal Valley, 1954-2003}

In order to estimate the environmental evolution consecutive to the rainfall increase, the analysis is focused on the Senegal Valley, an area of 13075 ha covered by all four aerial photos from 1954 (Fig. 6) to 2003 (Fig. 7). 


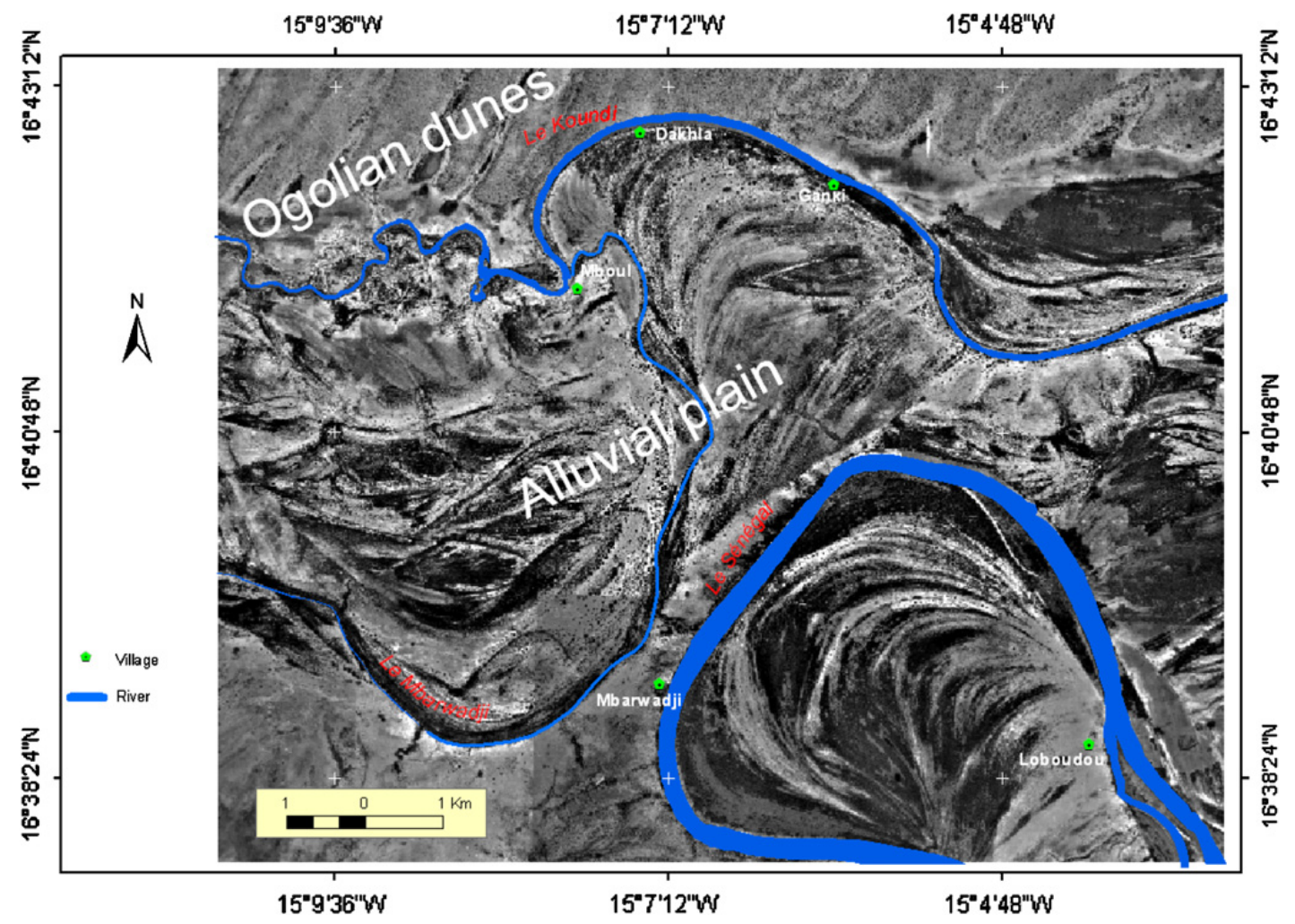

Fig. 6. Aerial photo of the Senegal Valley in 1954.

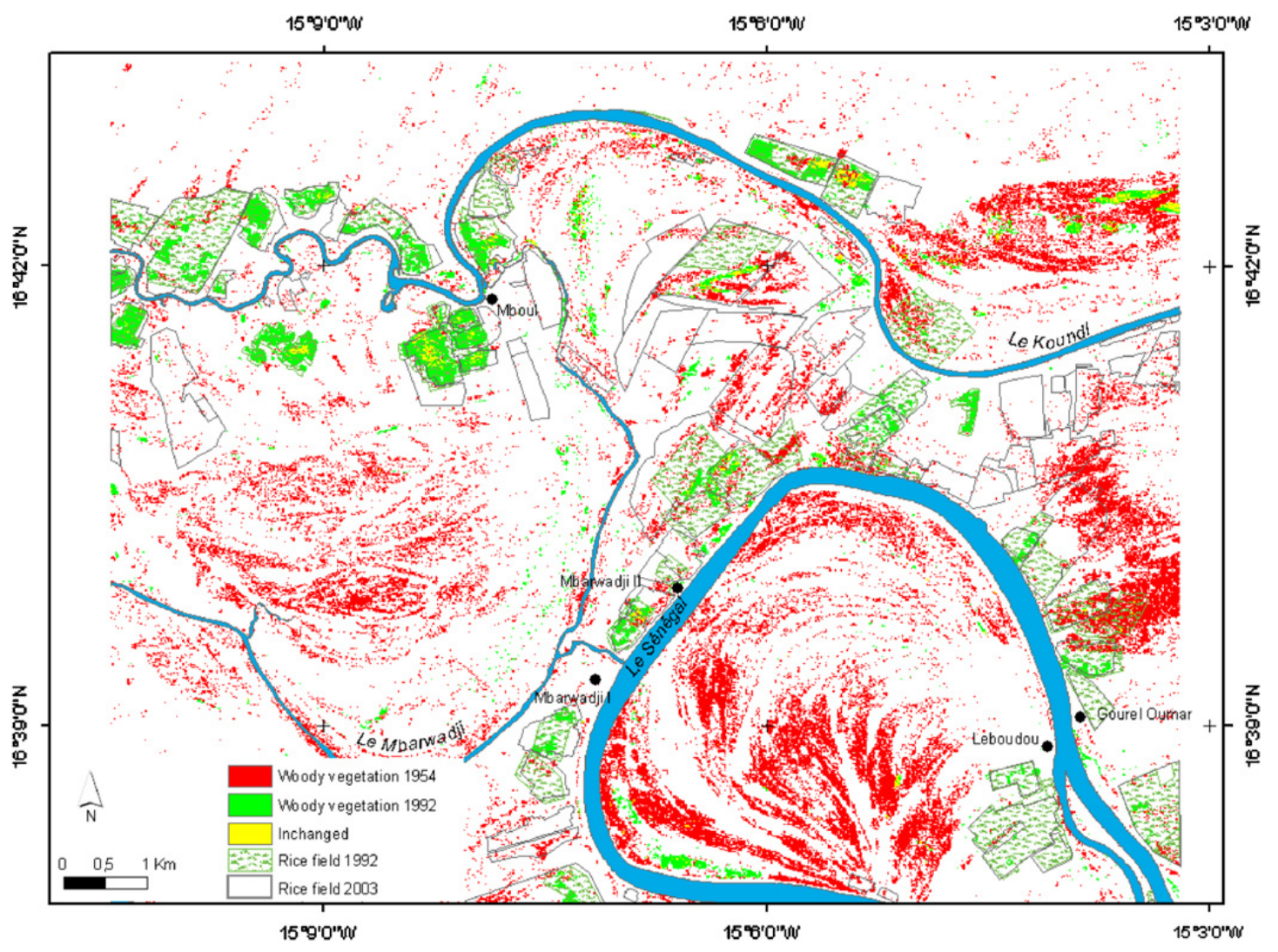

Fig. 7. Evolution of the vegetation in the Senegal Valley between 1954 and 1992. 


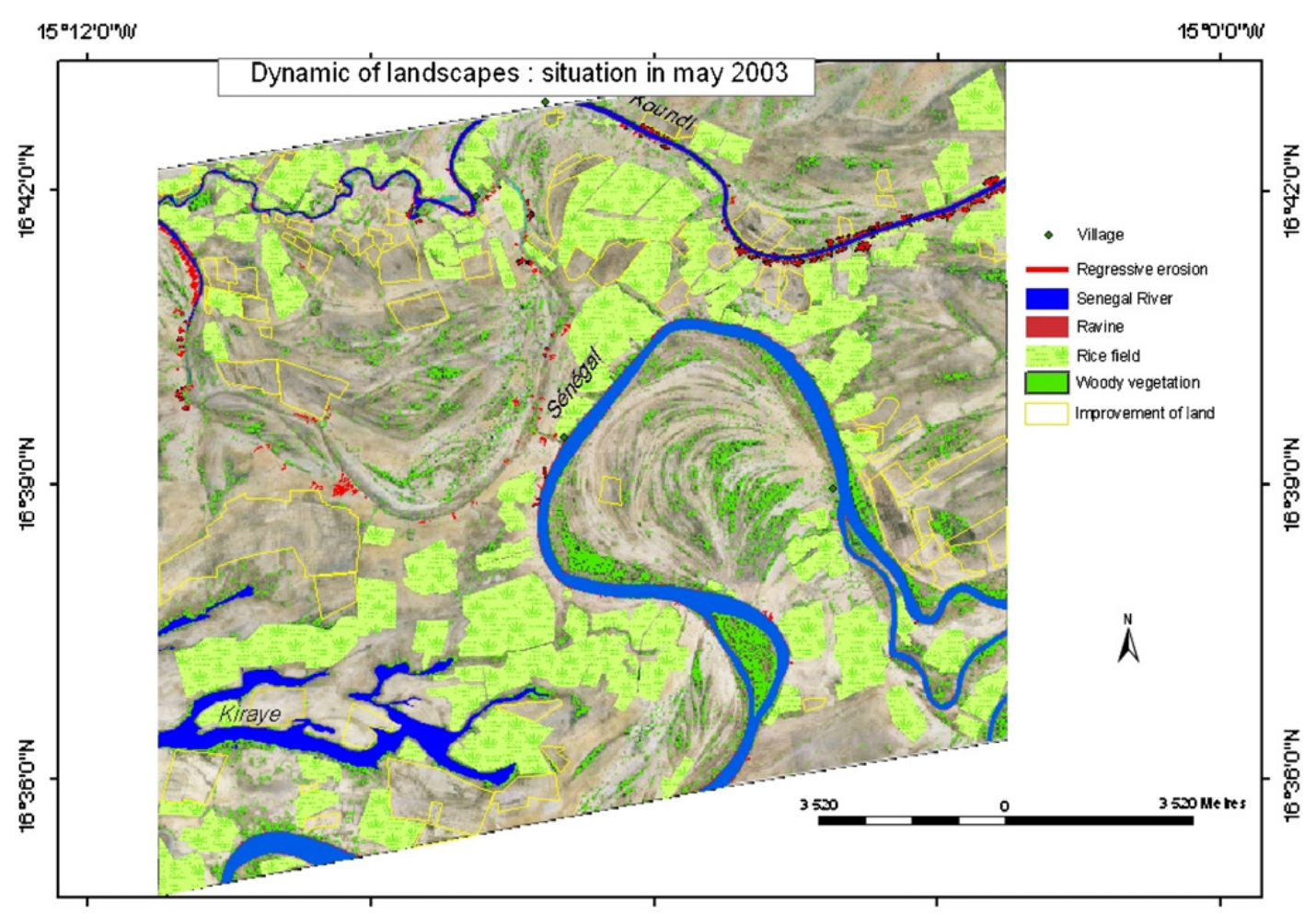

Fig. 8. Aerial photo of the Senegal Valley in 2003 and classification of selected land cover.

The analysis of all four airborne data clearly shows the continuous disappearance of forest cover from 2837 ha $(21.7 \%)$ in 1954 to 76 ha $(0.6 \%)$ in 2003 . If the forest reduction was of the order of $50 \%$ between the 1950s and the early 1970s, major changes occurred between 1972 and 1992 with surfaces declining from 1356 to $92 \mathrm{ha}$. The hypothesis that has been confirmed by local people is that forest contracted during the 1950s and the 1960s due to wood collection as fuel or for construction. Between 1972 and 1992, forest did not decline because of the drought but were cleared to welcome new rice fields. These were created thanks to the construction of two large dams realized to optimize water resources management of the Senegal River. Yet, inexistent before the dams, rice fields covered 1097 ha (8.4\%) in 1992 and 1987 ha $(15.2 \%)$ in 2003, with a total of 4300 ha $(32.9 \%)$ ready to be used. Another environmental evolution to note is the regeneration of some woody areas in the alluvial plain (south-eastern part of Figs. 7 and 8) between 1992 and 2003. In this specific area, all Acacia senegal totally disappeared between 1972 and 1992 (Fig. 7). Recent observed greening of this area (Fig. 8) is only due to the proliferation of Prosopis juliflora, an exotic invasive species (Wezel, 2004).

Regeneration of vegetation can be observed in very limited areas where anthropogenic pressure is small such as in fields protected by fences. But the most interesting process in the last 10 years is the development of several types of water erosion that clearly appear in red in Fig. 8 such as backward erosion, gullying, bank erosion and the creation of badlands that did not exist before. These new processes are favoured by the low vegetation cover and by the return of rainfall that are likely to be characterized by heavy events (Ozer and Ozer, 2005).

\section{Conclusion}

This diachronic analysis realized from climatic and airborne data allowed us to understand the landscape evolution in an area of south-western Mauritania during the last 50 years.

As observed in most other places of the Sahel, land degradation did not start directly with rainfall shortages but later on due to the intensification and the persistence of the precipitation deficit. In addition, increasing human pressure has been a constant during the period of analysis. Crests of fixed dunes have been reactivated during the 1980s, vegetation contracted during the same period, and forests almost disappeared during the 
second-half of the 20th century. A clear return to more normal precipitation did not provoke a significant greening of the natural features of the landscape. This explains why wind erosion still remains a major environmental parameter in the dune area north of the Senegal Valley. In addition, this low vegetation cover created perfect conditions for water erosion (gullying, badlands) that did not exist previously.

However, destruction of the forests and other features did not give place to bare desert-like soils. At the contrary, most of these areas have been replaced by rice fields after the construction of two dams to optimize water resources management of the Senegal River. These areas may therefore show a good resilience of vegetation from space when the analysis is realized based on low resolution satellite data such as the Pathfinder series of NOAA-AVHRR (Anyamba and Tucker, 2005; Eklundh and Olsson, 2003; Nicholson et al., 1998; Prince et al., 1998) but do not represent the true evolution of the environment. In other words, man continues land degradation except when large enterprises well financed allow land improvement, but at the detriment to protected forests.

\section{References}

Anyamba, A., Tucker, C.J., 2005. Analysis of Sahelian vegetation dynamics using NOAA-AVHRR NDVI data from 1981-2003. Journal of Arid Environments 63, 596-614.

Arnaud, J.C., 1999. Répartition de la population sédentaire. Évolution des densités de la population sédentaire (1977-1988). Les filières migratoires: les migrations dans le Trarza. In: de Rouen, L., de Nouakchott, L. (Eds.), Atlas de Mauritanie. Coopération française, Rouen, France, Planches 3, 5, 6e.

Dai, A., Lamb, P.J., Trenberth, K.E., Hulme, M., Jones, P.D., Xie, P., 2004. The recent Sahel drought is real. International Journal of Climatology 24, 1323-1331.

Eklundh, L., Olsson, L., 2003. Vegetation index trends for the African Sahel 1982-1999. Geophysical Research Letters 30, 1430.

Gonzalez, P., 2001. Desertification and a shift of forest species in the West African Sahel. Climate Research 17, $217-228$.

Hickler, T., Eklundh, L., Seaquist, J.W., Smith, B., Ardö, J., Olsson, L., Sykes, M.T., Sjöström, M., 2005. Precipitation controls Sahel greening trend. Geophysical Research Letters 32, L21415.

Hiernaux, P., Turner, M.D., 2002. The influence of farmer and pastoralist management practices on desertification processes in the Sahel. In: Reynolds, J.F., Stafford Smith, D.M. (Eds.), Global Desertification: Do Humans Cause Deserts? Dalhem University Press, Dalhem, pp. 135-148.

Hountondji, Y.C., Sokpon, N., Ozer, P., 2006. Analysis of the vegetation trends using low resolution remote sensing data in the Sahel (1982-1999) for the monitoring of desertification. International Journal of Remote Sensing 27, 871-884.

L'Hôte, T., Mahé, G., Somé, B., Triboulet, J.P., 2002. Analysis of a Sahelian annual rainfall index from 1896 to 2000 ; the drought continues. Hydrological Sciences Journal 47, 563-572.

Nicholson, S., 2005. On the question of the "recovery" of the rains in the West African Sahel. Journal of Arid Environments 63, 615-641.

Nicholson, S.E., Tucker, C.J., Ba, M.B., 1998. Desertification, drought, and surface vegetation: an example from the West African Sahel. Bulletin of the American Meteorological Society 79, 815-829.

Nouaceur, Z., 2003. Crise climatique et mutation des paysages en Afrique sub-saharienne: la dynamique des paysages autour de la ville de Nouakchott et dans la région de Rosso (Mauritanie). Sécheresse, 1E 〈http://www.secheresse.info/article.php3?id_article $=221\rangle$ (last access: 31/08/06).

Olsson, L., Eklundh, L., Ardö, J., 2005. A recent greening of the Sahel-trends, patterns and potential causes. Journal of Arid Environments 63, 556-566.

Ozer, P., 2000. Les lithométéores en région sahélienne: un indicateur climatique de la désertification. GEO-ECO-TROP. Revue internationale d'Ecologie et de Géographie Tropicales, 24, 1-317.

Ozer, A., Ozer, P., 2005. Désertification au Sahel: Crise climatique ou anthropique? Bulletin des Séances de l'Académie royale des Sciences d'Outre-Mer, 51, 4, 395-423.

Ozer, P., Erpicum, M., Demaree, G., Vandiepenbeeck, M., 2003. The Sahelian drought may have ended during the 1990s. Hydrological Sciences Journal 48, 489-492.

Pearce, F., 2002. Africans go back to the land as plants reclaim the desert. New Scientist 175, 4-5.

Pettitt, A.N., 1979. A non-parametric approach to the change-point problem. Applied Statistics 28, 126-135.

Prince, S.D., Brown de Colstoun, E., Kravitz, L.L., 1998. Evidence from rain-use efficiencies does not indicate extensive Sahelian desertification. Global Change Biology 4, 359-374.

Rasmussen, K., Fog, B., Madsen, J.E., 2001. Desertification in reverse? Observations from northern Burkina Faso. Global Environmental Change 11, 271-282.

Salama, M., Deconinck, J.N., Lofty, M.F., Riser, J., 1991. L'ensablement de Nouakchott: exemple de l'aéroport. Sécheresse 2, 101-109.

Sivakumar, M.V.K., Hatfield, J.L., 1990. Spatial variability of rainfall at an experimental station in Niger, West Africa. Theoretical and Applied Climatology 42, 33-39. 
UNFPA (Fond des Nations Unies Pour la Population), 2005. 〈http://mauritania.unfpa.org/datarim.htm〉(last access: 31/08/06).

Wezel, A., 2004. Local knowledge of vegetation changes in Sahelian Africa-implications for local resource management. In: Lykke, A.M., Due, M.K., Kristensen, M., Nielsen, I. (Eds.), The Sahel. SEREIN Occasional Paper No. 17. Institute of Geography, Copenhagen, Denmark, pp. 37-52.

World Meteorological Organization, 1992. International Meteorological Vocabulary. WMO, Geneva.

World Meteorological Organization, 1996. Guide to Meteorological Instruments and Methods of Observation, WMO no. 8. WMO, Geneva. 